\title{
Influence of silica intoxication on female reproductive organs with therapeutic agents vitamin $\mathrm{E}$ and vitamin $\mathrm{C}$
}

\author{
Shruti Saxena* and S. P. Singh \\ PG Department of Zoology, D. B. S. (PG) College, Dehradun, 24800 (Uttarakhand), INDIA \\ *Corresponding author. E-mail: Shruti_dsp@yahoo.com
}

\begin{abstract}
The aim of the present study was to observe the alteration of blood biochemical and histopathological variables after silica exposure, and also to show whether therapeutic agents (Vitamin E + Vitamin C) used in study may provide recovery against exposure to silica. In this study, silica was administered as silicon dioxide at a dose of $40 \mathrm{mg} / \mathrm{kg}$ for 28 days to produce toxic effect. Recovery pattern was evaluated by Vitamin E + vitamin C (50 mg/kg, ip $+100 \mathrm{mg} / \mathrm{kg}$, po), The present study showed alterations in the activities of oestrogen and LH were significantly decreased in experimental rats after 28 days of silica intoxication. The level of progesteron and $\mathrm{FSH}$, were also decreased. Therapeutic agents i.e. vitamin $\mathrm{E}$ and vitamin $\mathrm{C}$ recouped the values to normal and near to control.
\end{abstract}

Keywords: Histopathological variables, Recovery pattern, Blood biochemical, Silica

\section{INTRODUCTION}

Silica is one of the most fibrogenic material found in nature. Chronic inhalation of crystalline or free silica by workers, especially sandblasters, miners, tunnellers, silica millers, abrasives and flour workers, ceramic workers, glassmakers, and quarry and foundry workers leads to a pulmonary fibrosis called silicosis The distribution of silicon in nature is similar to the distribution of carbon in organic matters. Silicon contributes to about $28 \%$ of the earth's crust. Silicon being very reactive does not remain in the element form but combines either with oxygen alone and forms free silica $\left(\mathrm{SiO}_{2}\right)$ or with oxygen and other elements and forms silicates, example- Asbestos (Jaffrey et al., 1999; Magnani et al., 1998; Wilson et al., 1994 and Weiss, 2000).About 17 lakhs people are employed in various occupations such as mining andS quarries, 06.3 lakhs in manufacturing of nonmetallic products such as glass, mica etc, and 06.7 lakhs are engaged in manufacture of basic metals and alloys i.e. iron \& steel and 54 lakhs construction workers are also at risk of silica exposure. There are about 3 million workers at high potential risk of silica exposure (Yucesoy, 2001). Smokers are at an increased risk as smoking and silica act synergistically in causing chronic obstructive disease in the lung (Hnizdo et al., 1991; Hnizdo 1990; Malmberg et al., 1993). The environmental protection agency (EPA) has also evaluated silicon dioxide and silica gel and found them to be of moderate to low toxicity (40 CFR, 1992). $\mathrm{LD}_{50}$ of silica through intraperitoneal route is $40 \mathrm{mg} / \mathrm{kg}$ of body weight (Vanessa et al., 1996).

The aim of the present study was to evaluate the therapeutic effectiveness of vitamin $\mathrm{E}$ and vitamin $\mathrm{C}$ against silica induced toxicity. The importance of vitamin $\mathrm{E}$ in maintaining neurological structure and function has been well documented in clinical research (Packer and Landvik, 1989).

\section{MATERIALS AND METHODS}

Adult female albino rats of Sprague Dawely strain weighing $150 \pm 10 \mathrm{~g}$. were selected for the study were housed under standard conditions $\left(25^{\circ} \pm 2^{\circ} \mathrm{C}\right.$ temp, 60 $70 \%$ relative humidity and $12 \mathrm{~h}$ photoperiod) and allowed to food and water ad libitum.

The dose of toxicant, $\mathrm{SiO}_{2}$ was prepared in normal saline. Vitamin E was dissolved in olive oil and vitamin C was dissolved in distilled water.Study protocol was divided into three groups of five animals each. Group 1 was normal control and received normal saline; groups 2 and 3 were administered silicon dioxide at a dose of $40 \mathrm{mg} / \mathrm{kg}$ for 28 days. Group 2 was treated as experimental control and received saline for 5 days after toxicant exposure. Group 3 received therapeutic agents (combination of vitamin $\mathrm{E}$ + vitamin C (50 mg/kg, ip and $100 \mathrm{mg} / \mathrm{kg}$, po) respectively for 5 days.

Blood was collected from animals by puncturing the retroorbital sinus and samples were centrifuged and obtained serum was stored in a refrigerator for the analysis of progesteron, oestrogen, FSH and LH, (Kit method (CHOD- PAP method, No. 1117678.0001) from Merk). Immediately after necropsy, female reproductive organs (ovary and uterus) were excised. For histopathological study, the organs were fixed in Bouin's solution and heamatoxylin-eosin stained slides were observed for 

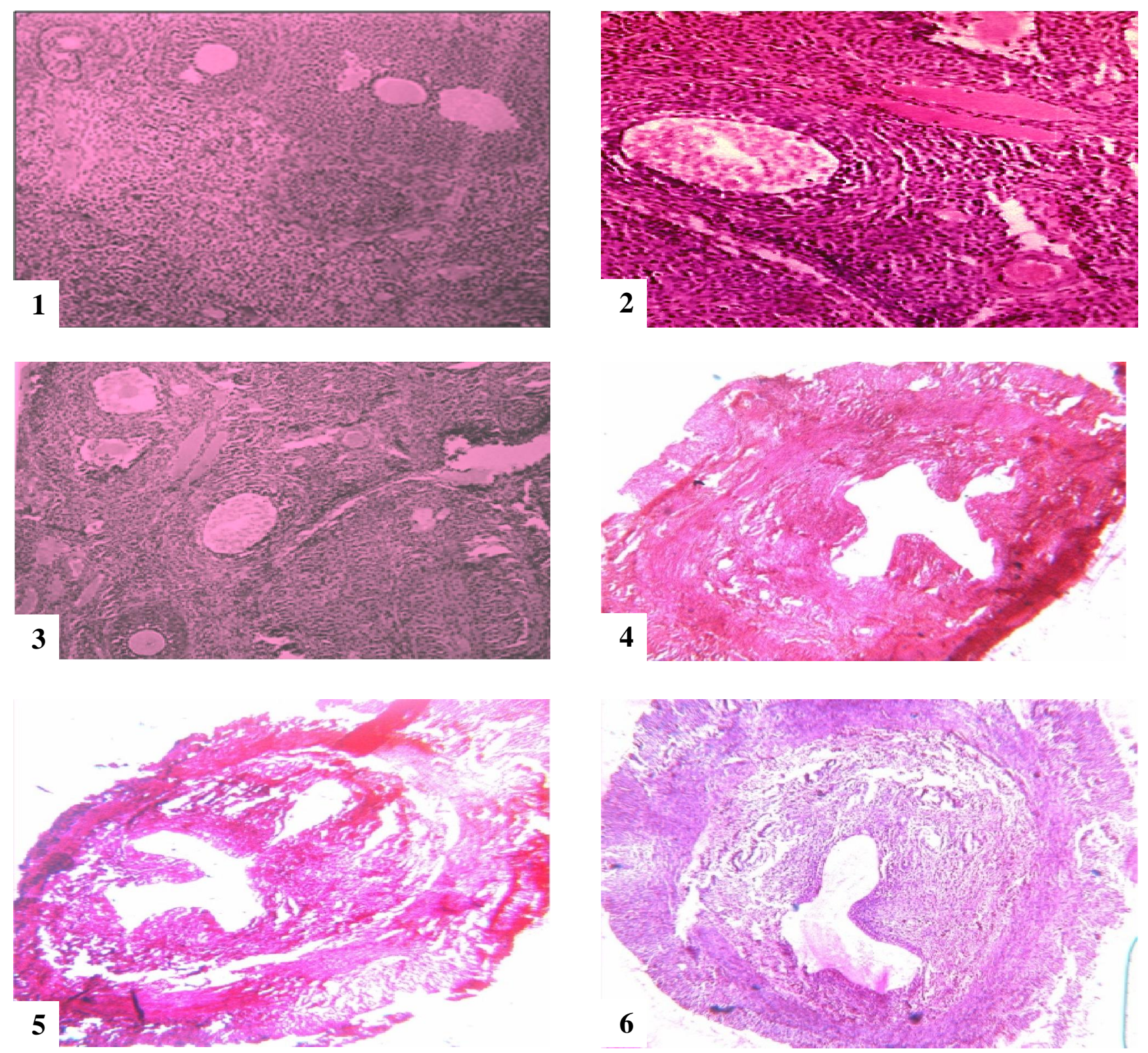

PLATE 1. Influence of silica intoxication on female reproductive organs with therapeutic agents vitamin e and vitamin c. Fig. 1-6. 1.T. S. of 0 vary of albino rat of control group. the normal cellular organization with all kinds of follicles, stroma and vascularity, X100. 2. Silica Exposure caused atrophic changes in the developing follicles and loose stroma with normal vascularity, X100.3. Treatment with vitamin $\mathrm{E}$ and vitamin $\mathrm{C}$ after silica administration showed significant improvement in ovary architecture, follicles, stroma, vascularity and carpora lutea also seen, X100. 4. T. S. of U terus of albino rat of control group. Note the normal histoarchitecture of endometrium, uterine lumen, uterine glands, musculature and vascular ity, X100. 5. Administration of silicon Dioxide, showing atrophic changes in the uterine musculature, uterine glands \& endometrium, X100. 6. Treatment with vitamin E and vitamin $C$ after silica administration improved the uter us architecture to a great extent. Showed si gnificant improvement in uterine musculature, uterine glands, uterine lumen and vascul arity, X100.

changes. Photomicrographs were taken for histopathological observation. All results were ex pressed as means \pm SE. Comparisons between two independent groups were made by the Students ' $\mathrm{t}$ ' test and $\mathrm{P}<0.05$ was considered statistically significant. The Statistical package for the Social Sciences (SPSS) packed program for Windows was used for the statistical analysis.

\section{RESULTS}

$\mathrm{SiO}_{2}$ administration did not cause significant effect on body weight. Weights of female Sex organs (ovary and uterus) were decreased remarkably after 28 days of $\mathrm{SiO} 2$ administration, (Table 1). The present study showed alterations in the various blood parameters after intraperitoneal intoxication of silicon dioxide. Activities 
of Oestrogen and LH were significantly decreased in experimental rats after 28 days of silica intoxication. The level of progesteron and FSH, were also decreased. Therapeutic agents i.e. vitamin $\mathrm{E}$ and vitamin $\mathrm{C}$ recouped the values to normal control (Table 2).

H istopathological studies (Platel): Photomicrograph of the T. S. of ovary of albino rat of control group. Showing the normal cellular organization with all kinds of follicles, stroma and vascularity (Fig. 1). Silica Exposure caused atrophic changes in the developing follicles and loose stroma with normal vascularity (Fig. 2). Treatment with vitamin $\mathrm{E}$ and vitamin $\mathrm{C}$ after silica administration improved the ovary architecture to a great extent. It showed significant improvement in follicles, stroma, vascularity and carpora lutea also seen (Fig. 3).

Photomicrograph of the T. S. of Uterus of albino rat of control group. Showing the normal histoarchitecture of endometrium, uterine lumen, uterine glands, musculature and vascularity (Fig. 4). Silica Exposure caused atrophic changes in the uterine musculature, uterine glands and endometrium (Fig. 5). Treatment with vitamin E and vitamin $\mathrm{C}$ after silica administration improved the uterus architecture to a great extent. It showed significant improvement in uterine musculature, uterine glands, uterine lumen and vascularity (Fig. 6).

\section{DISCUSSION}

Female hormones are produced by the ovaries and released by the follicles as they mature, responsible for female sexual characteristics, oestrogen stimulates and triggers a response from at least 300 tissues, and may help some types of breast cancer to grow. After menopause, the production of the hormone gradually stops. During the menstrual cycle, oestrogen renders the female genital tract suitable for fertilization, implantation, and nutrition of the early embryo. Pharmaceutical preparations of oestrogen are used in oral contraceptives to prevent pregnancy, palliate certain types of postmenopausal breast cancer and prostatic cancer in male, inhibit lactation, and treat threatened abortion and ovarian disease. Oestrogen replacement therapy may be prescribed to relieve the vasomotor symptoms of menopause. Its long-term continued use increases the risk of endometrial carcinoma. The present study demonstrates that 28 days after administration of silicon di oxide in rats, there is a significant decrease in the activities of steroidogenic enzymes and fall of serum levels of FSH, LH, Oestrogen and progesterone . Similar study demonstrates that 28 days after administration of lead acetate in rats, there is a significant decrease in the activities of steroidogenic enzymes and fall of serumlevels of FSH, LH (Biswas and Ghosh, 2004). The changes in ovarian - architecture depends upon the pituitary gonadotrophins viz F.S.H. and L.H. which are in turn
Table 1. Showing body, ovary and uterus weight.

\begin{tabular}{lccc}
\hline Group & $\begin{array}{c}\text { Body weight } \\
\text { (gm) }\end{array}$ & $\begin{array}{c}\text { Ovary } \\
(\mathrm{mg})\end{array}$ & $\begin{array}{c}\text { Uterus } \\
\text { (mg) }\end{array}$ \\
\hline Control & $150 \pm 10 \mathrm{gm}$ & $70 \pm 10$ & $115 \pm 10$ \\
$\mathrm{SiO}_{2}$ & $146 \pm 10$ & $58 \pm 10$ & $95 \pm 10$ \\
$\mathrm{SiO}_{2}$ Vit E+vit C & $148 \pm 10$ & $65 \pm 10$ & $100 \pm 10$ \\
\hline
\end{tabular}

*Significant, ns not significant $\mathrm{P}$ value $\mathrm{SiO}_{2} \mathrm{~V}$ s control at $\mathrm{a} \leq 0.05$, $\mathrm{b} \leq 0.01, \mathrm{P}$ value drugs $\mathrm{Vs} \mathrm{SiO}_{2}$ at $c \leq 0.05, \mathrm{~d} \leq 0.01$

regulated by their respective releasing factor (Lerner 1969). On the contrary, progesterone reported to inhibit the post coital ovulation in rabbit and is said to impair the ovarian steroidogenesis.

In the present study, no significant change in body weight of the rats was observed after 28 days of administration of silicon dioxide @ $40 \mathrm{mg} / \mathrm{kg}$. The ovarian and uterine weight were decreased insignificantly. The histology of the ovary underwent changes in their cellular organization. The developing follicle, the maturing follicles and the fully developed follicles became atretic follicles. The dose ( $40 \mathrm{mg} / \mathrm{kg}$ body weight) of silica for 28 days. The histoarchitecture of uterus also underwent many changes in their cellular organization. The uterine lumen ,the endometrial cells height and uterine glands were reduced. The results noticed in the present study on histopathology of genital organs are comparable to the studies made by Chakraborti et al. (1968) when the female rats were fed with green leaves of Artobotry odoratissimus. Follicular atresia and degeneration changes which have similarly with the present observation, were also reported by Kholkute and Udupa (1974) and Kholkute et al. (1976) following the treatment of extract of Hibiscus rosasinensis flowers.

A typical oestrogen is well known to stimulate all the uterine histological structure in rats by increasing the number of uterine glands and stromal cells (Everett. 1962). It also increase the growth of serosa and musculature. The glandular epithelium become columnar with basal deposition of nuclei along with an increase in leucceytic infiltration, musculature and vascularity,(Karkun and Mehrotra, 1973). The results revealed that $P$. bettle ethanolic extract $(50 \%)(100 \mathrm{mg} /$ day/rat $)$ for 30 days did not change the body and vital organ weights, but the reproductive organ weights diminished significantly $(\mathrm{P}<0.001)$ as compared to control rats (Table 1). As the structural and functional integrity of reproductive organ depend on circulating level of estrogen, any small change in estrogen level may lead to altered structural and functional activity of reproductive organs(Sharma et al., 2007). In the present study, a non stimulatory effect of silica was observed. Thus, the antifertillity effect of silica may be due to hormonal imbalance in the ovarian and uterine tissues. When these silicotic rats were treated with a combination of vitamin $\mathrm{E}$ and vitamin $\mathrm{C}$, the 
Table 2. Showing the level of female reproductive hormones in normal control, experimental and treated group.

\begin{tabular}{lcccc}
\hline Group & $\begin{array}{c}\text { Estrogen } \\
\mathrm{ng} / \mathrm{ml}\end{array}$ & $\begin{array}{c}\text { Progesteron } \\
\mathrm{ng} / \mathrm{ml}\end{array}$ & $\begin{array}{c}\mathrm{LH} \\
(\mathrm{ng} / \mathrm{ml})\end{array}$ & $\begin{array}{c}\mathrm{FSH} \\
(\mathrm{ng} / \mathrm{ml})\end{array}$ \\
\hline Control & $9.96 \pm 0.16$ & $62.21 \pm 0.47$ & $38.62 \pm 0.32$ & $195.32 \pm 0.67$ \\
$\mathrm{SiO}_{2}$ & $7.8 \pm 0.15$ & $41.9 \pm 0.41$ & $27.28 \pm 0.38$ & $160.12 \pm 0.65$ \\
$\mathrm{SiO}_{2}$ Vit E+vit C & $8.1 \pm 0.17$ & $53 \pm 0.34$ & $33.0 \pm 0.28$ & $173.02 \pm 0.51$ \\
\hline
\end{tabular}

*Significant, ns not significant $\mathrm{P}$ value $\mathrm{SiO}_{2}$ Vs control at $\mathrm{a} \leq 0.05, \mathrm{~b} \leq 0.01$, $\mathrm{P}$ value Drugs $\mathrm{Vs} \mathrm{SiO}_{2}$ at $c \leq 0.05, \mathrm{~d} \leq 0.01$

histopathological changes of ovary and uterus were significantly recouped. The elevated reproductive hormone levels as studied and their values are a testimonial to the recoupment of structural organization of reproductive organs.

\section{REFERENCES}

Biswas, N. M. and Ghosh P. K. (1994). Effect of thyroidectomy, and thyroxine and $\alpha 2 \mathrm{u}$ - globulin replacement theraphy on testicular steroidogenic and gametogenic activities in rats. J Endocrinol., 140: 343 - 347.

Biswas, N. M. and Ghosh P. K. (2004). Effect of lead on male gonadal activity in albino Rats. Kathmandu U niversity Medical J ournal, 2 (1): 43-46.

CFR (1992). Exemptions from the requirement of a tolerance. Code of Federal Regulations, Vol. 40:413.

Chakarborti, S., Chaudhary, A. and Chaudhary, R.R. (1968). Antifertility effect of green leaves of Artobotrys odoratissimus Linn. J . Indian M ed. Ass., 51 (5): 227 - 229.

Everett, J. (1962). The influence of oestradiol and progesterone on the endometrium of the guinea pig in vitro. . Endocrinol., 24: 491-496.

Hnizdo, E. and Sluis-Cremer, G. K., (1991). Silica exposure, silicosis and lung cancer: A mortality study of south African gold miners. Br. J. Ind. M ed., 48: 53 .

Hnizdo, E., (1990). Combined effect of silica dust and tobacco smoking on mortality from chronic obstructive lung disease in gold minters. Br. J. Ind. M ed., 47: 656

Jaffrey, L. L., O’Sullivan, M. F., Corn, C. J., Williams, M. G. and Dodson, R. F., (1999). Asbestosis and small lung cancer in a clutch refabricator. Occup. Environ. M ed., 56: 602.

Karkun J. N. and Mehrotra P. K. (1973). Studies on physiology and biochemistry of female genital tract; Response of uterus, cervix and vagina of albino rat to cis-transclomiphere in the presence or absence of oestrogen. Indian J. Exp. Biol., 11 (7): 14.

Kholkute, S.D. and Udupa, K.N. (1974). Antifertility properly of Hibiscus rosa sinensis Linn. J. Res. Indian M ed., 9 (4) : $99-102$.

Kholkute, S.D., Chatterjee, S. and Udupa, K.N. (1976). Effect of Hibiscus rosasinensis flower on oestrus cycle and reproductive organs in rats. Indian J. Exp. Biol., 14 : 703.
Lerner, L. J. (1969). The biology of non steroidal antifertility agents in contraception, chemical control fertility. Daniel Lednicer Marcel Dekker Inc.P. 161.

Magnani, C., Mollo, F., Paoletti, L., Bellis, D., Bernardi, P., Betta, P., Botta, M., Falchi, M., Ivaldi, C. and Pavesi, M., (1998). Asbestos lung burden and asbestosis after occupational and environmental exposure in an asbestos cement manufacturing area: a necropsy study. 0 ccup. Environ. Med., 55: 840

Malmberg, P., Hedenstrom, H. and Sundblad, B. M., (1993): Changes in lung function of granite crushers exposed to moderately high silica concentrations: A 12 -year follow-Up. $\mathrm{Br}$. J. Ind. M ed., 50: 726 .

Packer, L. and Landvik, S., (1989). Vitamin E: Introduction to biochemistry and health benefits. In: Diplock, A. T., Machlin, J. L., Proyr, W. A., (Eds), Vitamin E, Biochemistry and health implications. New York Acad. of Science, New York. 1: 6.

Sharma, J.D., Sharma, L. and Yadav, P. (2007). Antifertility efficacy of Piper betle Linn. (Petiole) on female Albino Rats. Asian J. Exp. Sci.,21 (1): 145-150

Suresh, C. and Tiwary, R. S., (1999). Free radicals in health and disease. Everyman's Sciences, 33:149.

Vallyathan, V., Shi, X., Dalal, N. S. and Castranova, V., (1988): Generation of free radicals from freshly fractured silica dust: potential role in acute silica induced lung injury. Am. Rev. Respir. Dis., 138:1213.

Vanessa, V, Barrett, C., Roycroft, J., Schuman, L., Dankovic, D., Baron, P., Martomen, T., Papelko, W. and Lai, D., (1996). Workshop Report. Chronic inhalation toxicity and carcinogenicity testing of respirable fibrous particles. Regul. Toxicol. and Pharmacol., 24: 202.

Weiss, W., (2000). Asbestosis and lober site of lung cancer. Occup. Environ. M ed., 57: 358.

Wilson, R., Langer, A. M., Nolan, R. P., Barnard, J., Gee, L. and Ross, M., (1994). Asbestos in New York city public school buildings- public policy: is there a scientific basis. Reg. Toxicol. and Pharmacol., 20: 161.

Yucesoy, B., Vallyathan, V., Landsittel, D. P., Sharp, D. S., Wewton, A., Burleson, G. R., Simionova, P., McKinstry, M. Luster, M. I. ((2001). Association of tumor necrosis factor- $\alpha$ and interleukin- 1 gene polymorphism with silicosis J. Toxicol. and appl. P harmacol., 172: 75 . 